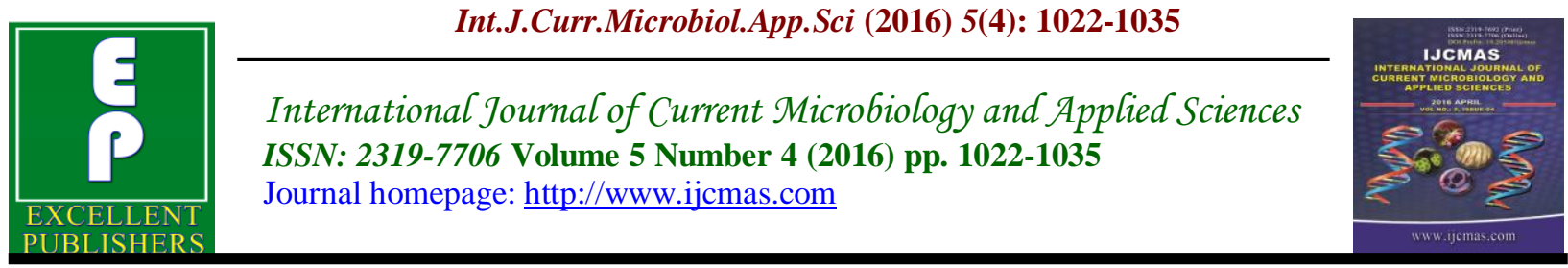

Review Article

http://dx.doi.org/10.20546/ijcmas.2016.504.117

\title{
Immuno-defense Strategy in Earthworms: A Review Article
}

\author{
Shruti Gupta and Shweta Yadav* \\ Department of Zoology, School of Biological Sciences, Dr. H. S. Gour University, \\ Sagar, M.P., India \\ *Corresponding author
}

\begin{abstract}
A B S T R A C T
Keywords

Earthworm, immune-defense, toxicants, exposure, detoxification, immunocytes.

\section{Article Info}

Accepted:

09 January 2015

Available Online:

10 April 2016

Earthworms are relatively well known group of soil invertebrates and represents significant part of soil biomass. They are routinely exposed with variety of soil microorganisms as well chemical toxicants. Earthworms have developed powerful immunodefense system to potentially escape from pathogenic environment by evoking the immune system and to maintain the self integrity. Earthworm emerges as immuno-defense model because of their strong, well developed innate immunodefense mechanism strategy against stressed environment. Coelomic cavity of earthworm consists immunocytes/coelomocytes, homologous to vertebrate's leukocytes. Their immunity may potentially involved in detoxification of chemicals including, metal contaminants, pesticides and removal of pathogenic microbes. Their immuno-defense mechanism activates cellular signaling cascade at exposure of contaminants including, nanoparticles by releasing several factor like antimicrobial peptides, PAMPs (pathogen associated molecular pattern), cytotoxic molecules, serine protease pathways. This review aims to understand important cellular and humoral pathways to develop immuno-defense strategy in earthworms that may assist in detoxification of toxicants.
\end{abstract}

\section{Introduction}

Immunity of an organism is a complex system for organism's survivability and integrity. In general, immunity acts like a security barrier for pathogenic environment by defending themselves against invasion of intruders as well as self generated deformed/altered substances. Immune system includes various components like cells, molecules (proteins) and gene that triggers activation of various pathways of the immune response to recognize the nonself molecules.
That act against it to prevent hazardous impact like diseases/ infections by eliminating it from self component. Mechanism of immune responses and their action against pathogen/noxious substances, broadly classified into two categories, innate and adaptive immunity. Innate immunity presents in all organisms as their natural immunity since birth upto the whole life of organisms and is considered as most primitive and simplest form of immunity. 
Expression of innate immunity is always "on" but their action start immediately, after exposure of antigen within a short period. This acts like first line of defense for nonspecific response against foreign/antigen molecule but it is not able to discriminate the types of antigen because they do not memorize the antigen encounter reaction which has been done previously. After exposure of antigen, innate immunity devour the invaders by means of phagocytosis other associated mechanism of elimination. If it is not happening in that particular regular pathway then they invoke the activation of adaptive immunity just to maintain self integrity and their viability. Adaptive or acquired immunity, are memory based immune responses with high specificity to foreign particles. Antigen encounters with the host and induces the activation of various components. It characterizes the antigen and memorized for the future response to perputate the host integrity. Biological system protects them by destroying and clearing out these digested debris of foreign bodies/particles outside the body. This immune response bears long lasting memory may be life long to act against the same antigen in future security. Annelids are supposed to be the first animal in Phylogenetic tree in which both cellular and humoral immune responses are developed (Dainaut and Scaps, 2001).

\section{Invertebrate's Immune Responses}

During late 0s Nobel Prize winner Elie Metchnikoff described innate immunity mediated by phagocytosis and their importance in eradication of foreign contaminants in Asterias (Beck and Habicht, 1996; Bilej et al., 2010). Soil fertility, regularly checked by their inhabitant faunal diversity and are also indicator for chemical contaminants in soil (Lanno et al., 2004). Directly or indirectly soil resident invertebrates are exposed to soil for their basic need (Kammenga et al., 2000). Among all invertebrates, soil earthworms are key organism 69 for soil formation and degradation of organic matter in soil. Majority of soil faunal diversity build by earthworms (more than 80\%) (Kale, 1997; Nainawat and Nagendra, 2001; Lalthanzara et al., 2011) and are much susceptible to wide range of pathogens that may cause elucidate infection, harmful effect to the host body. Earthworm's immunity play active role against its foreign pathogenic world and developed immuno-defense strategy. This make them model organism for immunological studies (Cooper and Roch, 2003; Bilej et al., 2010). Majority of study has been done on vertebrate's immunity but very limited information available (Bilej et al., 2010) in concern with invertebrates including, earthworm's immunity (Dainaut and Scaps, 2001). During the life cycle of various commercial products, the chemical toxicants like heavy metals, pesticides, hydrocarbons and nanoparticles may be released from these products through normal use that may reaches in wastewater streams that became threat to soil 80 ecosystems. All these anthropogenic activity raises the stress into the environment, may fatal to all tropic level of food chain/web (Kammenga et al., 2000). Therefore, terrestrial eco-systems are expected to be an ultimate sink for a large portion of contaminants. This raises concern about the Immuno-defense strategy in soil organism to encounter these contaminants and earthworms may be potential to organism to bioremediate these contaminants.

\section{Earthworm: Perspective Model for Immuno-Competence}

Earthworm's immunity is most ignorant area of study as compared to other invertebrates 
like Drosophila and Caenorhabditis elegans. In early 1960s first significant study (Cooper and Roch, 2003) were reported in earthworms during the experiment analysis by allo and xeno graft rejection mechanism based on inflammatory and cellular immune defense responses. This helped to becomes earthworm as model organism for immune function and their importance in ecological perspectives. As higher organisms, earthworm also possesses both cellular as well as humoral immunity. Earthworm secondary body cavity (coelomic cavity) mesodermal in origin filled with free suspended immuno-protective cells, coelomocytes and also releases various types of humoral factors. This help in earthworm's survivability and integrity against wide range of pathogens, chemical contaminants including pesticides, heavy metals, petroleum hydrocarbon and also nanoparticles of soil ecosystem (Lionetto et al.,2012; Gupta et al.,2014). Coelomic fluid of earthworm potentially controls the pathogens on wide scale (Beschin et al., 1998; Cooper and Roch, 2003; Bilej et al., 2010) with immuno-defense mechanism through cascade and cellular signaling (Copper et al., 2012) pathways.

\section{Immuno-response in Earthworms}

Earthworms belong to the class Oligochaeta of phylum Annelida, are long tubular worm like structure with different variable measurement of size $10 \mathrm{~mm}$ to 7 meters long (Julka, 2008). Their Body covered with soft and permeable skin with a layer of cuticle and are metamerically segmented (each segment is separated by septa) with true coelom/body cavity. Coelomic cavity filled with coelomic fluid suspended with coelomocytes and different types of proteins/ peptides. Coelomocytes are the immune cells of earthworm which provide immune defense mechanism against wide range of foreign bodies. This act as toxicological biomarker which play role in the transportation of toxicants throughout the worm's body (Cooper et al., 2002, Lionetto et al., 2012). Earthworm body lack in skeleton but their coelomic cavity acts like a hydrostatic skeleton which supports its body in various physiological functions like locomotion, movement etc. The flow of coelomic fluid from one segment to another segment is guarded by channels which is present in each segment of body (Cameron, 1932; Bilej et al., 2010). Their body segment is perforated with a pair of nephridia and a pair of dorsal pore that expelled the coelomic fluid at the time of requirement or stress. Body wall of earthworm is slippery moist due to the release of coelomic fluid and mucous from dorsal pore which helps in locomotion, burrowing, entrapping the nutrients/chemicals from soil environment. Their moist body wall rich in coelomocytes, proteins and peptides that lead to immune defense mechanism against foreign bodies, pathogens. Their coelomic fluid may toxic to other vertebrate organism as reported by Salzet et al. (2006) in Eisenia fetida. Soil pathogen/foreign bodies start invades through their body wall that invoke their immune responses against pathogen.

\section{Cellular Immune Responses in Earthworm}

Almost all organisms possess their outer surface coating called skin, that covers the body from the exposure of the outer environment and protect the biological system from microbial/chemical invasion. Epidermis of earthworms acts like a biological barrier for non specific pathogenic foreign bodies. Therefore, their epidermis potentially protects the worm from dermal exposure of pathogens. Skin also secretes polysaccharide mucous/ 
coelomic fluid, rich in coelomocytes and peptides through nephridial/dorsal pores. These pores are also behaving like a portal of entry for soil bacteria from external soil environment to reach inside the earthworm's body. Microbial invasion may affect the sterility of coelomic fluid. Coelomocytes immediately initiate encapsulation devour invaded engulf pathogens that eliminated out from the body as suggested by Dales and Kalac (1992). Bilej et al. (2010) reported phagocytic cells numbers ten times higher than that naturally occurring microbial count total microbial count (6x105/ml)in earthworm coelomic fluid.

\section{Calcium Signaling Pathways in Earthworms}

Calcium is a primitive molecule, involved in various physiochemical cell signaling pathways viz., gene transcription, muscles contraction and proliferation of cell including their role in immune responses (Petersen et al., 1994; Berridge et al., 1998; Case et al., 2007; Engelmann et al., 2011). Larger proportions of $\mathrm{Ca} 2+$ occupy endoplasmic reticulum and sarcoplasmic reticulum which reaches to other cell organelles including mitochondria and nucleus (Melendez, 2005); Bootman and Lipp, 2001). They also recorded a small compartment of calcium, as calciosomes in many cell. Pryor et al. (2000) stated endosomes and phagosomes also stores calcium in vertebrate leukocytes by activation of calcium signaling. $\mathrm{Ca} 2+$ also play an important role to induce cell to cell signaling which are related to presence and influx of calcium ion responsible for activation of coelomocytes during exposure of foreign bodies in earthworm (Engelmann et al., 2011). It also act like a secondary messenger (Whitekar, 2006), elevation of intracellular calcium and transient oscillation in the mediator of coelomocytes activation and their metabolism (Engelmann et al., 2011). However, limited literature is available regarding role of calcium signaling in invertebrates, including earthworms (Burlando et al., 2001; Whitaker, 2006; Engelmann et al., 2011). Several type of influx channel present on plasma membrane for sufficient supply of calcium ion from intercellular space that maintain the cytosolic concentration $\mathrm{Ca} 2+$ and promote the diverse set of switch "on" and "off" mechanism on plasma membrane (Bootman and Lipp, 2001). Intracellular calcium ion concentration increases due to kinase phosphorylation, activation of transcription factors and expression of selected gene (Ohhora and Rao, 2008; Engelmann et al., 2011). Molecularly characterized protein calreticulin is a calcium binding evolutionary conserved protein that highly expressed in earthworm's coelomocytes as comparison to their other body tissue (Kauschke et al., 2001). Engelmann et al. (2011) assessed subpopulation of coelomocytes, effect or coelomocytes granular, hyaline amoebocytes and chloragocytes for measurement of calcium ion. Characteristic differences were recorded in level of intracellular calcium in effector coelomocytes and in chloragocytes (Opper et al., 2010).

Calcium ion also plays important part in the formation and maturation of phagosome. That initiates the release of $\mathrm{Ca}^{2+}$ from endoplamic reticulum and activates the SOCE channels in the plasma and phagosomal membrane as well. These elevate the oscillatory $\mathrm{Ca}^{2+}$ concentration and helps in the ingestion of foreign particles/pathogen. $\mathrm{Ca}^{2+}$ is also an important intermediate for solublization of actin network that covers the phagosome during beginning of phagosome formation and fusion of phagosome with granules containing lytic enzymes (Nunes and Nicolas, 2010). 


\section{Immunocytes in Earthworm}

Cellular immune response in earthworms depends on activation of various cellular components of their coelom fluid including coelomocytes/immunocytes as well various releasing factors like peptides and proteins. These coelomocytes differentiated on the basis of functional and morphological behavior into three sub populationeleocytes, amoebocytes, and granulocytes. Earthworm's coelomocytes are structurally and functionally similar to vertebrate's leukocytes (Beck and Habicht, 1996; Cooper and Hirabayashi, 2013).

They performed cell-cell adhesion, pattern recognition, phagocytosis, encapsulation, opsonization, lysis, agglutination, inflammation, mitogenesis, rejection and destruction of non-self (allogeneic and xenogeneic) components (Fig.1) from self component with weak memory in-vivo and in-vitro as well (Cotuk et al., 1984; Cossarizza et al.,1996; Bilej et al., 2010; Cooper and Hirabayashi, 2013). Eleocytes (chloragocytes) are significant immunodefence cell (Lionetto et al., 2012). They remain attached to intestinal lining as chloragogenic tissue and after getting mature, detached from lining. That becomes free-floating in the form of eleocytes (chloragocytes) (Jamieson, 1981; Jamieson, 1992; Affar et al., 1998).

These cells act as a liver in earthworm which are similar to higher organism, helps in detoxification including metal pollution (Cholewa et al., 2002; Kwadrans et al., 2008; Plytycz et al., 2009; Lionetto., 2012). It is supposed chloragogen tissues helps in synthesis of hemoglobulin, to maintain constant cationic concentration and ionic balance in coelomic fluid of earthworm (Prento, 1979, Lionetto et al., 1994; Hatti, 2013). These tissues also play very important role in heavy metal exposure and detoxification of toxic cation like $\mathrm{Zn}, \mathrm{Cd}$ etc. (Lionetto et al., 1994; Gupta et al., 2014). They also impart extracellular respiratory pigments and helps in storage of glycogen and lipids (Needham, 1966; Roots and Johnston, 1966; Fischer, 1977; Affar et al., 1998).

Eleocytes produces bactericidal effects or substances that participate in encapsulation and brown body formation of larger foreign pathogen to eliminate them from the body (Cooper and Stein, 1981; Valembois et al., 1992; Valembois et al., 1994; Hatti, 197 2013).Amoebocytes are another type of adherent coelomocytes derived from mesenchymal lining of coelom may be hyaline or granular (Cooper and Stein, 1981). Those helps in wound healing, and also have coagulation property beside transport and storage of nutritive molecules (Adamowicz and Wojtaszek, 2001). Both hyaline and granular amoebocyte have potential to phagocyte foreign bodies followed by pattern recognition multi-phase immune activation that further lead to removal of noxious material from the host body. Cytoplasm of hyaline amoebocytes trap and engulf foreign bodies other lipopolysaccharide, peptidoglycon, betaglucan etc. Eleocytes and amoebocytes are effectory immune defence cell responsible for humoral immunity of worms as well (Cooper and Roch, 1986; Jarosz and Glinski, 1997).Granulocytes, are spherical with centrally located nuclei, acidophilic in nature filled with eosinophilic granules, comprises upto $28 \%$ volume of total coelomocytes content (Adamowicz and Wojtaszek, 2001).

\section{Formation of Brown Bodies by Coelomocytes of Earthworms}

Coelomocytes recognizes the pattern of pathogen, initially free moving cells gather around the foreign body (like invading 
bacteria and particulate wastes), forming the dense capsule, that appears in form of dark brown pigmented aggregates due to presence of melanin pigment, lipofuschin, called as brown bodies (1-2mm in size). This may be due to catabolism of insolublization of oxidized organic substrates (Cholewa et al., 2006). That process happens with the help of prophenoloxidase cascade and finally eliminated out from the body (Valembois $e t$ al., 1992). Brown body formation usually seen in Eisenia fetida, that are enriched in self tissue wastes, agglutinated bacteria and pathogens as well (Valembois et al., 1992), which are further degraded by encapsulation as described in Fig.2.

Figure.1 Expected Phagocytosis Mechanism in Immunocytes/Coelomocytes of earthworm,1.Oxygen dependent, Oxidative burst initiated by monophosphate shunt, transfer the e- to the NADPH Oxidase. NADPH Oxidase complex present on phagosomal membrane and produce O2- (superoxide anion) and singlet Oxygen. Conversion of O2- leads to the production of $\mathrm{H} 2 \mathrm{O} 2$ (hydrogen peroxide) and then $\mathrm{H} 2 \mathrm{O} 2$ may generates the activated $\mathrm{OH}$ (hydroxyl radical).all together release of these different $(\mathrm{OH}$ radical, O2-,singlet Oxygen, $\mathrm{H} 2 \mathrm{O} 2)$ are enough toxic to catalyse the degradation of pathogen/foreign particle potentially. 2. Oxygen independent, fusion of lysosome with phagosome leads to the formation of phago-lysosome, in which lysozymes catalyse the cell wall of foreign particles in low $\mathrm{pH}$. (modified after Morgan and DeCoursey, 2003; Cross and Segal,2004)

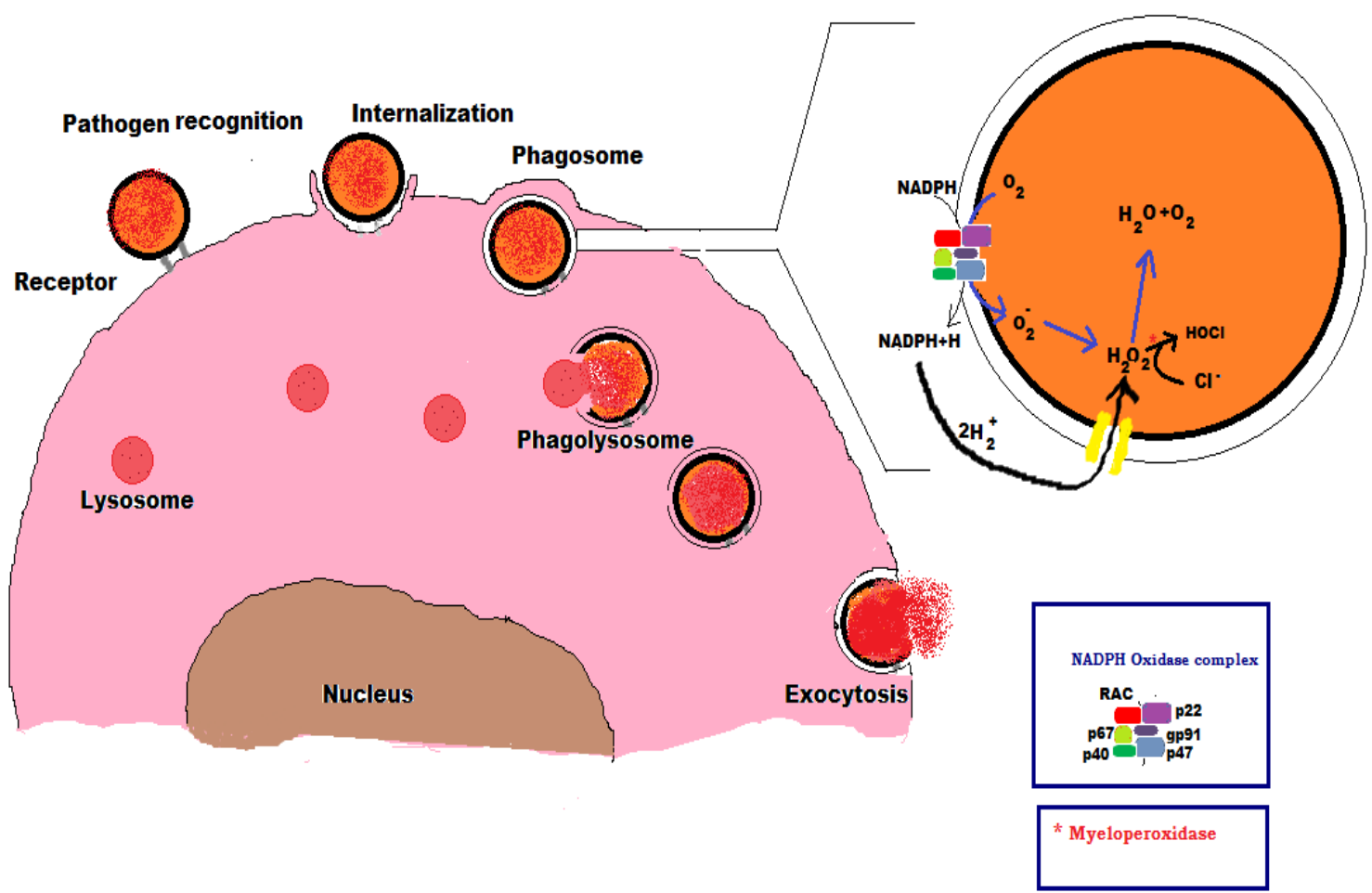


Figure.2 PAMPs (Pathogen Associated Molecular Patterns) are the molecular signature of pathogens like PGRPs (Peptidoglycan Recognition Proteins) Gram +ve bacteria, LPS and GNBPs (Lipopolysaccharide and Gram negative bacteria binding proteins) Gram -ve bacteria, $\beta-1,3$-Glucan for fungal pathogen, recognized by immune cells that initiate the activation of serine protease cascade. Serine protease hydrolyzed and activating the prophenoloxidase activating protease (proPAP) to PAP. Serpine are the inhibitor of PAP activation. PPO (prophenoloxidase) hydrolysed by PAP enzymes and converted into activated form PO (phenoloxidase). PO initiate the oxidation of tyrosine to L-3,4dihydroxyphenylalanine (DOPA) further oxidized to dopachrome and then developed into quinones, which is the precursor of melanin that act release the various antimicrobial factors. (Modified after Beschin et al., 1998; Garcia et al., 2009).

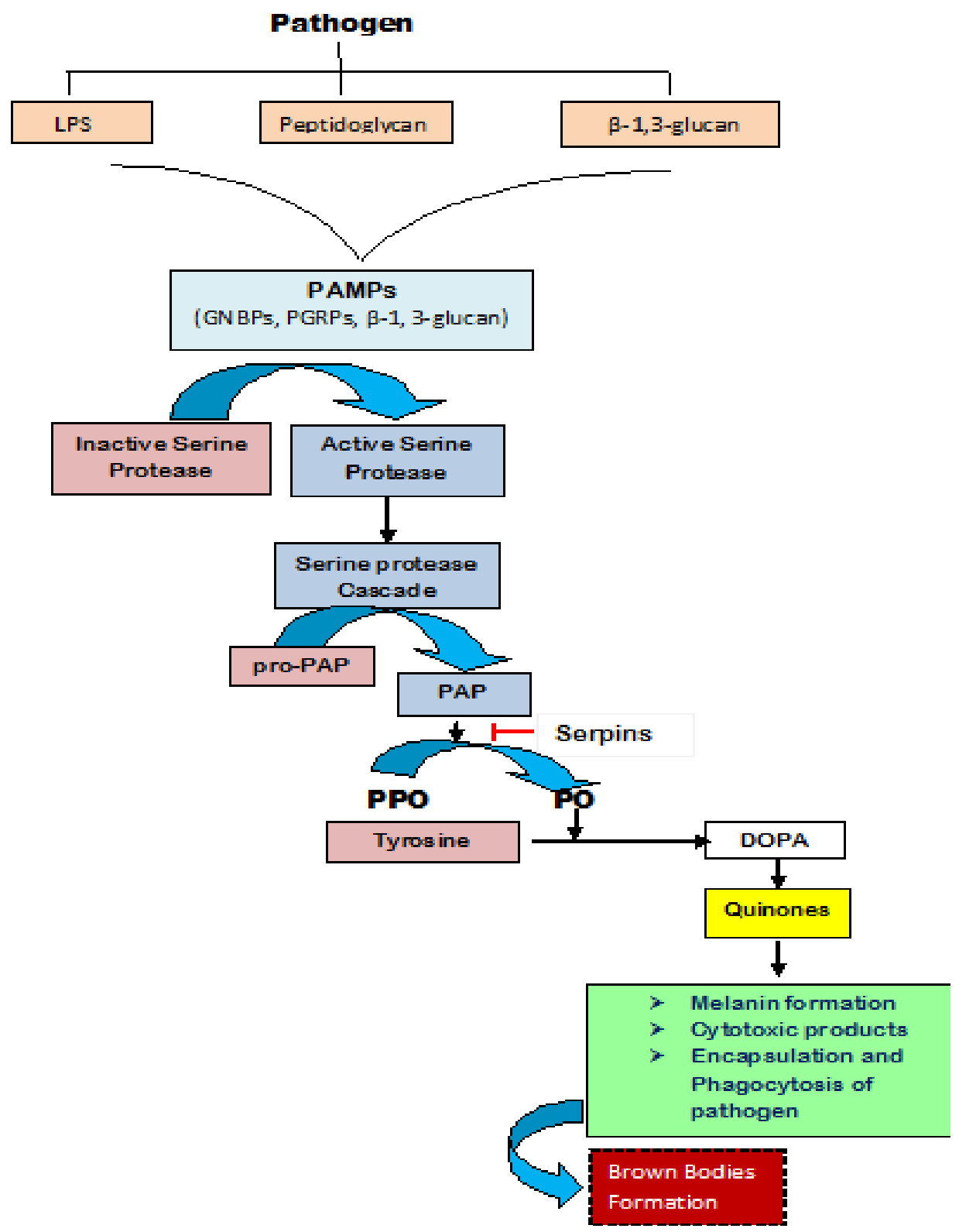




\section{Humoral Immune-defense Mechanism in Earthworms}

Coelomic fluid of earthworm is known to act against wide range of pathogen and devour them potentially (Opper et al., 2012). Quaglino et al., (1996), Joskova et al., (2009) suggested varieties of immunological factors in coelomic fluid of earthworm to maintain their self integrity. These bioactive factors are present in the form of lysozymes, antimicrobial peptides (or proteins) (Cho et al., 1998; Wang et al., 2003; Liu et al., 2004), hemolytic factors like hemagglutination etc. (Bilej et al., 2010). Their fluid also have the potential to digest eukaryotic cell either of same species of different earthworm or other organism like hemocytes of insects and various other derivatives of vertebrates cellular components (Salzet et al., 2006). Their Lysozymes, hydrolytic enzyme shows bactericidal effect against the gram positive peptidoglycan cell wall by catalyzing the intermediate linkage. Thus, they are potentially capable for eradication of gram positive infection in earthworms and may act as sensitive biomarker for $\mathrm{Cu}$ ion load and its toxicity in earthworms (Goven et al., 1994).

\section{Role of Antimicrobial Peptides in Immune Responses}

Coelomic fluid of earthworm possesses various kinds of antimicrobial peptides of diverse group of different molecular weight. They can enrich the coelomic fluid with strong hemolytic, cytotoxic, hydrolytic, agglutination and opsonization. They are present in different isomeric forms (proline rich antimicrobial peptides Lumbricin I) of antimicrobial peptides in different earthworm sp. Lumbricin I hemolytic activity was first reported in Lumbricus rubellus by Cho et al. (1998). Isomer of
Lumbricin I, PP-1 (Wang et al., 2003) in Pheritima tschiliensis imparts antimucosal defense mechanism in earthworms (Wang $e t$ al., 2003).

Recently OEP3 identified in Eisenia fetida (Wang et al., 2003) that possess antineoplastic potential and have ability to destroy human cancer cell lines (Cooper et al.,2004). Eisenia fetida andrei factor (EFAF) factor contribute efficient proportion in antimicrobial peptides. They have the high ability to lyse the hemoglobin (hemolysis) and other eukaryotic cells. EFAF antimicrobial peptide, either kill the noxious bacteria or arrest the bacterial growth during exposure of pathogen contaminated soil as reported by Du Pasquier and Duprat (1968). That may be bactericidal/ bacteriostatic for pathogenic form of bacteria and protect the worm against wide range of gram positive and gram negative bacterial infection. This hemolytic factor exhibit the agglutination of erythrocytes of blood which may promote the cytotoxic effect (Kauschke and Mohrig, 1987) for foreign bodies That also released by eletrocyte in two forms of antimicrobial strong hemolytic peptides namely, fetidin and lysenin. They exhibit antibacterial activity against both Gram-positive and Gram-negative bacteria (Valembois et al., 1982; Lassegues et al., 1989) particularly against strains that are pathogenic for earthworms (Roch et al., 1991; Roch et al., 1987; Valembois et al., 1986). In addition to their bacteriolytic activity, they may also mediate opsonization ( Sinkora et al., 1993) and participate in the clotting of the coelomic fluid ( Valembois et al., 1988). It was documented, that upon binding to sphingomyelin, a major lipid constituent of plasma membranes of most mammalian cells, polymerize and form 10-nm channels through the lipid bilayer (Roch et al., 1981; Roch et al., 1989). Antimicrobial peptide 
(40kD) fetidin, of E. fetida have heat labile peptide similar to hemolytic property of vertebrate and other eukaryotic biological system. Ten genetic families of fetidin, characterized with four alleles were reported by Roch et al. (1987). Their similarity between these subfamilies depends on presence of aspartic acid, glutamic acid and glycine (Roch et al. 1981). This contributes in dermal secretion of mucous, that may checked out the non-pathogenic bacteria population via serine protease/serine protease inhibitor pathway (Valembois et al., 1985). During the activation of cell, serine protease release from the cell otherwise it exists as inactive form and remain stored in cell. Another, antimicrobial peptide Lysenin $(41 \mathrm{kD})$ were isolated from Eisenia fetida that shares biochemical activities in worm along with two other peptides fetidin and eiseniapore. (Sekizawa et al., 1997). Lysenin exhibits contractile properties as it is experimentally observed in smooth muscle of rat and also impart hemolysis as well because they have high affinity towards sphignomyelin rich cellular membrane such as RBCs, spermatozoa (Cooper and Roch, 2003). Recent study (Bruhn et al., 2006) revealed the few other sub family (multi gene) of lysenin, that has been cloned and known as Lysenin-related protein. Lysenin are highly homologus to fetidin in amino acid sequence (Bilej et al., 2010) and comprises homologous genes. However, variations were recorded in their functional expression in different species of earthworms (Prochazkova et al.,2006). The active form of lysenin were also observed in mature free chloragogen tissue in lumen of typhlosole region of intestine (Opper et al., 2012).

\section{Role of Coelomic Cytolytic Factors (CCF)}

CCF (42-kDa protein), were observed in soluble form in coelomic fluid of earthworm
Eisenia fetida that performs patternrecognition molecule activity (Kohlerova et al., 2004). That released by mesenchymal lining of coelomic cavity and free moving coelomocytes.

This helps worm in immunodefense mechanism like cytotoxicity, opsonization and hemolysis of foreign bodies (Beschin et al., 1998). Molecular characterization and cloning of CCF-1 shows strong homology with the catalytic region of $\beta-1,3$ - and $\beta-1$, 3-1, 4- glucanases, coagulation factor $G$ from Limulus polyphemus and Gram -ve bacteria binding protein in Bombyx mori (Beschin et al.,1998). That comprises two distinct domain of lectin, PAMPs (pathogen associated molecular pattern) binding site; there one domain central part of the molecule interacts with O-antigen of lipopolysaccharide (LPS) of gram negative and $\beta$-1,3-glucans of yeast and $C$-terminal tryptophan that interacts with peptidoglycan. PAMPs bind specifically invoke CCF to activate the prophenoloxidase (proPO) cascade (Valembois et al., 1986; Salzet et al., 2006).

\section{Conclusions}

1) Earthworms covers major proportion of soil ecosystem and live together with wide range of beneficial and pathogenic microbiota and also with anthropogenic soil toxicants.

2) Earthworms facilitate growth and population of these beneficial microbes to drive coordination of natural scavenging and detoxification of these toxicants.

3) Earthworm directly or indirectly exposed to these contaminants and potentially evoked their immune cells activity. 
4) Their immune system contributes in detoxification of metallic ions toxicity which enters in their body either from ingestion of soil or interstitial pore water of soil in contact with dermal opening of nephridial pore or dorsal pore. A variety of bioactive molecules and peptides present in coelomic fluid of earthworm that helped them to detoxify from soil ecosystem.

5) This review is recollection of information regarding earthworms' survivability in toxic/ pathogenic environment and their immuno-defense strategy. The contributed data is in the favor of earthworm as a immuno-defense model of soil ecosystem.

\section{References}

Adamowcz, A., Wojtaszek, J. 2001. Morphology and phagocytotytic activity of coelomocytes in Dendrobaena veneta (Lumbricidae). Zoologica Poloniae, 46: 91-104.

Affar, E.B., Dufour, M., Poirier, G.G., Nadeau, D. 1998. Isolation, Purification and partial characterization of chloragocytes from the earthworm species Lumbricus terrestris. Mol. Cellular Biochem., 185: 123-133, 314.

Azzolina, L.S., Demuri, C., Prati, G., Robotti, M. 1985. Phylogenesis of immunocompetent cells. Bollentino Zoologia, 52: 167-187.

Beck, G., Habicht, G.S. 1996. Immunity and invertebrates. Scientific American, 275: 60-63, 318 .

Berridge, M.J. 1998. Neuronal calcium signaling. Neuron, 21: 13-26.

Beschin, A., Bilej, M., Hanssens, F., Raymakers, J., Dyck, E.V., Revets, L.B., Gomej, J., Baetselier, P.D., Timmermans, $\quad$ M. 1998.
Identification and cloning of a Glucan- and Lipopolysaccharide binding protein from Eisenia fetida earthworm involved in the activation of prophenoloxidase cascade. J. Biol. Chem., 273: 24948-24954.

Bilej, M., Prochazkova, P., Silerova, M., Joskova, R. 2010. Earthworm Immunity. Invertebrate Immunity, 708: 66-79.

Bootmann, M.D., Lipp. P. 2001. Calcium signaling and regulation of cell function. John Wiley and Sons.

Bruhn, H., Winkelmann, J., Andersen, C., Andre, J., Leippe, M. 2006. Dissection of mechanism of Cytolytic and antibacterial activity of lysenin, a defence protein of annelid Eisenia fetida. Developmental Comparative Immunol., 30: 597606.

Burlando, B., Panfoli, I., Viarengo, A., Marchi, B. 2001. Free radicaldependent $\mathrm{Ca} 2+\quad$ release. Antioxidation and Redox Signal, 3: 525-530.

Cameron, G.R. 1932. Inflammation in earthworms. J. Pathol., 35: 933-972.

Case, R.M., Eisner, D., Gurney, A., Jones, O., Muallem, S., Verkhratsky, A. 2007. 335 Evolution of calcium homeostatis from birth of the first cell to an omnipresent signaling 336 system. Cell Calcium, 42: 345-350.

Cho, J.H., Park, B., Yoon, Y.G., Kim, S.C. 1998. Lumbricin I, a novel prolinrich antimicrobial peptides from the earthworm: purification, cDNA cloning and molecular characterization. Biochimica Biophysica Acta, 1408: 67-76.

Cholewa, J., Feeney, G., O'Reilly, M., Sturzenbaun, S.R., Morgan, A.J., Plytycz, B. 2006. Autofluorescence in Eleocytes of some earthworm 
species. Folia Histochemica Et Cytobiologica, 44: 65-71 .

Cooper, E.L., Kauschke, E., Cossarizza, A. 2002. Digging for innate immunity since Darwin and Metchnikoff. Bioessays, 24: 319-333.

Cooper, E.L., Roch, P. 1986. Second-set allograft responses in earthworm Lumbricus terrestris. Transplantation, 41: 514-520.

Cooper, E.L., Ru, B., Weng, N. 2004. Earthworm sources of antimicrobial and anticancer molecules. Advances in Experimental Medicine and Biol., 546: 359-389.

Cooper, E.L., Stein, E.A. 1981. Invertebrate blood cells. Academic Press, London San Francisco, 75-140.

Cooper, E.L., Roch, P. 2003. Earthworm immunity: a mode of immune competence. Pedobiologia, 47: 676688.

Cossarizza, A., Cooper, E.L., Suzuki, M.M., Salvioli, S., Capri, M., Quaglino, D. Franceschi, C. 1996. Earthworm leukocytes that are not phagocytic and cross-react with several human epitopes can kill human tumor cell lines. Experimental Cell Res., 224: 174-182.

Cotuk, A., Dales, R.P. 1984. Lysozyme activity in the coelomic fluid and coelomocytes 358 of the earthworm Eisenia fetida SAV in relation to bacterial infection. Comparative Biochem. Physiol., 78: 469-474.

Cross, A.R., Segal, A.W. 2004. The NADPH Oxidase of professional phagocytes-Proton of the NOX electron transport chain systems. Biochimica et Biophysica ActaBioenergetics, 1657: 1-22.

Dainaut, A., Scaps, P. 2001. Immune defense and biological responses induced by toxics 364 in Annelida. Canadian J. Zool., 79: 233-253.
Dales, R.P., Kalac, Y. 1992. Phagocytic defence by the earthworm Eisenia fetida against certain pathogenic bacteria. Comparative Biochem. Physiol., 101: 487-490.

Du Pasquier, L., Duprat. P. 1968. Humoral and cellular aspects of a non specific natural immunity in the oligochetee Eisenia foetida Savigny (Lumbricinae). C R Acad. Sci. Hebd Seances Acad. Sci. D., 266: 538-541.

Engelmann, P., Opper, B., Nemeth, P. 2011. Interactions of intracellular calcium and immune response in earthworm. Invertebrate Survival J., 8: 78-84.

Fischer, E. 1977. The function of chloragosomes, specific age-pigment granule of Annelids: a review. Experimental Generation, 12: 69-74.

Goven, A.J., Chen, S.C., Fitzpatrick, L.C., Venables, B.J. 1994. Lysozyme activity in earthworm (Lumbricus terrestris) coelomic fluid and coelomocytes: Enzyme assay for immunotoxicity of xenobiotics. Environ. Toxicol. Chem., 13: 607613.

Gupta, S., Kushwah, T., Yadav, S. 2014a. Toxicity of $\mathrm{ZnO}$ nanoparticles on earthworm Eisenia fetida (Savigny, 1826) and investigating its potential as bio-transforming agent. Advances in Earthworm Taxonomy VI (Annelida: Oligochaeta)-Eds., Tomas.

Pavlicek, Patricia Cardet, Maria Teresa Almeida, Claudia Pascoal, Fernanda Cassio. Proceedings of 6th International Oligochaete Taxonomy Meeting, Portugal Kasparek Verlag, Heidelberg, Germany. pp. 158-171.

Gupta, S., Kushwah, T., Yadav, S. 2014b. Earthworm coelomocytes as a nanoscavanger to $\mathrm{ZnO}-\mathrm{NPs}$. Nanoscale Res. Lett., 9: 259. 
Hatti, S.S., Ramakrishna, B. 2013. Extraction of coelomic fluid from the earthworm Perionyx sansibaricus for antibacterial activities. Indian $J$. Appl. Res., 3: 1-3.

Hostetter, R.K., Cooper. E.L. 1973. Cellular anamnesis in earthworms. Cellular Immunol., 9: 384-392.

Jamieson, B.M.G. 1981. Chloragocytes. In: The ultrastructure of the oligochaeta (Ed. Jamieson B.M.G.). Academic Press, New York.

Jamieson, B.M.G. 1992. Oligochaeta. In: Microscopic anatomy of Invertebrates. (Eds.Harrison, F.W. and Gardiner, S.L.), Wiley-Liss New York.

Jarosz, J., Glinski. Z. 1997. Earthworm immune response. Folia Biologica, 45: $1-9$.

Julka, J.M. 2008. Know your earthworm. Rashtriya Vigyan Evam Prodyogiki Sanchar Parishad, Govt of India.

Kale, R.D. 1997. Earthworms and soil. The Proceeding of the National Academy of Sciences, India 67: 13-24.

Kammenga, J.E., Dallinger, R., Donker, M.H., Kohler, H.R., Simonsen, V., Triebskorn, R., Weeks, J.M. 2000. Biomarkers in terrestrial invertebrates for Ecotoxicological soil risk assessment. Rev. Environ. Contamination and Toxicol., 164: 93-147.

Kauschke, E., Komiyama, K., Moro, I., Eue, I., Konig, S., Cooper. E.L. 2001. Evidence for perforin-like activity associated with earthworm leukocytes. Zool., 104: 13-24.

Kauschke, E., Mohrig. W. 1987. Comparative analysis of hemolytic and hemagglutinating activities in the coelomic fluid of Eisenia fetida and Lumbricus terrestris (Annelida, Lumbricidae).

Developmental
Comparative Immunol., 11: 331341.

Kohlerova, P., Beschin, A., Silerova, M., De Baetselier, P., Bilej, M. 2004. Effect of experimental microbial challenge on the expression of defense molecules in Eisenia fetida earthworm. Developmental and Comparative Immunol., 28: 701711.

Lalthanzara. H., Ramanujam. S.N., Jha. L.K. 2011. Population dynamics of earthworms in relation to soil physio-chemical parameters in agroforestry systems of Mizoram, India. J. Environ. Biol., 32: 599-605.

Lanno, R., Wells, J., Conder, J., Bradham, K., Basta, N. 2004. The bioavailability of chemicals in soil for earthworms. Ecotoxicol. Environ. Safety, 57: 39-47.

Lavelle, P., Spain, A. 2001. Soil ecology. Dordrect, Netherland, Kluwer Academic Publishers.

Lionetto, M.G., Calisi, A., Trifone, S. 2012. Earthworm Biomarkers as tools for soil pollution assessment, soil health and land use management, Dr Maria C. Hernandez Soriano (Ed.).

Liu, M., Hu, F., Chen, X., He, Y., Li, H. 2004. Effects of Different vegetation restoration of degraded red soil on earthworm population dynamics. Ying Yong Sheng Tai Xue Bao, 15: 2052-2156.

Melendez, A.J. 2005. Calcium signaling during phagocytosis. Molecular Mechanism of Phagocytosis, 9: 117132.

Morgan, D., De Coursey, T.E. 2003. Diversity of voltage gated proton channels. Frontier in Biosci., 8: 1266-1279.

Nainawat, R., Nagendra. B. 2001. Density and distribution of earthworms in different localities of Jaipur. J. Eco- 
Physiol., 4: 9-13.

Nunes, P., Nicolas. D. 2010. The role of calcium signaling in phagocytosis. $J$. 430 Leukocyte Biol., 88: 57-68.

Needam, A.E. 1966. The chloragogenpigment of earthworm. Life Sci., 5: 33-39.

Oh-Hora, M., Rao. A. 2008. Calcium signaling in lymphocytes. Curr. Opinion in Immunol., 20: 250-258.

Opper, B., Bognar, A., Heidt, D., Nemeth, P., Engelmann, P. 2012. Revising lysenin expression of earthworm coelomocytes. Developmental and Comparative Immunol., 39: 214218.

Opper, B., Nemeth, P., Engelmann, P. 2010. Calcium is required for Eleocyte activation in earthworms. Mol. Immunol., 42: 2047-2056.

Petersen, O.H., Petersen, C.C.H., Kasai, H. 1994. Calcium and hormone action. Ann. Rev. Physiol., 56: 297.

Plytycz, B., Lis-Molenda, U., Cygal, M., Kielbasa, E., Grebosz, A., Duchnowski, M., Andre, J., Morgan, A.J. 2009. Riboflavin content of coelomocytes in earthworm (Dendrodrilus rubidus) field populations as a molecular biomarker of soil metal pollution. Environ. Poll., 157: 3042-3050.

Prento, P. 1979. Metals and Phosphate in the chloragosomes of Lumbricus terrestris and 446 their possible physiological significance. Cell and Tissue Res., 196: 123-134.

Prochazkova, P., Silerova, M., Stijlemans, B., Dieu, M., Halada, P., Joskova, R., Beschin, A., Baetselier, P.D., Bilej. M. 2006. Evidence for proteins involved in prophenoloxidase cascade Eisenia fetida earthworms. J. Comparative Physiol. B., 176: 581-587.
Pryor, P.R., Mullock, B. M., Bright, N.A., Gray, S.R., Luzio, J.P. 2000. The role intraorganellar $\mathrm{Ca} 2+$ in late endosomes-lysosome heterotypic fusion and in the reformation of lysosomes from hybrid organelles. $J$. Cell Biol., 149: 1053-454, 1062.

Quaglino, D., Cooper, E.L., Salviole, S., Capri, M., Suzuki, M.M., Ronchetti, I.P., Franceschi, C., Cossarizza, A. 1996. Earthworm coelomocytes in vitro: cellular features and "granuloma" formation during cytotoxic activity against the mammalian tumor cell target K562. European J. Cell Biol., 70: 278-288.

Roch, P., Canicatti, C., Valembois, P. 1989. Interaction between hemolysins and sheep red blood cell membranes. Biochimica et Biophysica Acta, 983: 193-198.

Roch, P., Stabili, L., Pagliara, P. 1991. Purification of three serine proteases from the coelomic cell of earthworm (Eisenia fetida). Comparative Biochem. Physiol., 98: 597-602.

Roch, P., Valembois, P., Davant, N., Lassegues. M. 1981. Protein analysis of earthworm coelomic fluid. IIisolation and biochemical characterization of the Eiseniafetida andrei factor (EFAF). Comparative Biochem. Physiol., 467(69): 829836.

Roots, B.I., Johnston. P.V. 1966. The lipids and pigments of the chloragosomes of the earthworms, Lumbricus terrestris. Comparative Biochem. Physiol., 17: 285-470, 288.

Salzet, M., Tasiemski, A., Cooper, E. 2006. Innate immunity in Lophotrochozoans: the annelids. Current Pharma. Design, 12: 30433050.

Sekizawa, Y., Kubo, T., Kobayashi, H., Nakajima, T., Natori. S. 1997. 
Molecular cloning of lysenin, a novel protein in the earthworm Eisenia Fetida that causes contraction of rat vascular smooth muscle. Gene, 191: 97-102.

Sinkora, M., Bilej, M., Tuckova, L., Romanovsky, A. 1993. Hemolytic function of opsonizing proteins of earthworm's coelomic fluid. Cell Biol. Int., 17: 935-939.

Valembois, P., Lassegues, M., Roch, P. 1992. Formation of brown bodies in the coelomic cavity of the earthworm Eisenia fetida andrei and attendant changes in shape and adhesive capacity of constitutive cells. Developmental and Comparative Immunol., 16: 95-101.

Valembois, P., Lassegues, M., Roch, P., Vaillier, J. 1985. Scanning electronic microscopic study on the involvement of coelomic cells of earthworm antibacterial defense. Cell Tissue Res., 240: 479-484.

Valembois, P., Roch, P., Lassegues. M. 1986. Antibacterial molecules in annelids. In: Brehelin M. ed.
Immunity in Invertebrates. Berlin: Springer-Verlag. 74-93.

Valembois, P., Roch, P., Lassegues, M. 1988. Evidence of plasma clotting system in earthworms. Journal of Invertebrates Pathol., 51: 221-228.

Valembois, P., Roch, P., Lassegues, M., Cassand, P. 1982. Antibacterial activity of the hemolytic system from the earthworm Eisenia fetida Andrei. J. Invertebrate Pathol., 40: 21-27.

Valembois, P., Seymour, J., Lassegues, M. 1994. Evidence of Lipofuscin and melanin in the brown body of the earthworm Eisenia fetida andrei. Cell Tissue Res., 277: 183-188.

Wang, X., Wang, X., Zhang, Y., Qu, X., Yang, S. 2003. An antimicrobial peptide of the earthworm Pheretima tschiliensis: cDNA cloning, expression and immunolocalization. Biotechnol. Lett., 25: 1317-1323.

Whitaker, M. 2006. Calcium microdomains and cell cycle control. Cell Calcium, 40: 585-592.

\section{How to cite this article:}

Shruti Gupta and Shweta Yadav. 2016. Immuno-defense Strategy in Earthworms: A Review Article. Int.J.Curr.Microbiol.App.Sci.5(1): 1022-1035. doi: http://dx.doi.org/10.20546/ijcmas.2016.504.117 